\title{
ACCOUNTING AND FINANCIAL REPORTS IN THE FUNCTION OF CORPORATE GOVERNANCE
}

\author{
Jugoslav Aničić, ${ }^{1}$ Dušan Aničić, ${ }^{2}$ Aleksandar Majstorović, ${ }^{3}$ \\ 1, "Union-Nikola Tesla University", Faculty of Entrepreneurial Business, Serbia \\ ${ }^{2}$ DSN Consalting, Belgrade, Serbia \\ 3 "Union-Nikola Tesla University", Faculty for Real Estate Management, Belgrade, Serbia \\ ajugoslav@yahoo.com; anicic.dusan@yahoo.com; majstorovicaleksandar@gmail.com
}

\section{Professional Paper \\ doi:10.5937/jouproman5-13302}

\begin{abstract}
Market economy development is highly dependent upon accounting data reliability and financial report quality because the investors decide more easily on investments in the market which had earned trust and safety in the previous period. Big financial scandals from the beginning of the 21 st century and still actual financial crisis at the global level have especially contributed to that. The information prepared on the basis of high quality, transparent and comparable international standards considerably reduce investment risks as well as the cost of raising capital. On the other hand, the management of a large number of companies is focused on the creation of short-term personal benefits as opposed to the investors primarily interested in company survival and growth, that is, long-term goals. Information asymmetry is often present in the financial markets, and its damaging results, as a rule, are borne by shareholders and other stakeholders of the company. Corporate governance depends on legal, regulative and institutional environment, and it should balance the interests of the shareholders, capital owners, managers as well as company business managers.
\end{abstract}

Key words: accounting, financial reporting, corporate governance

\section{Introduction}

Financial reports represent the basic ways for companies to report on the success of their business and financial and property conditions for external interested parties. The companies that want to invest in other countries or collect funds in the international capital market have to compile financial reports understandable for business partners and investors. Therefore, the financial reports have to be made according to the accounting standards accepted in most developed countries. The need for international standard acceptance has its practical dimension because they equalise the accounting practices around the world, simplify stock exchange business outside the national borders and enable national and international market growth, as well as the complete economy.

True and honest financial reporting represent a first class public interest so the principle of the objective reporting should be the leading principle for the financial reports creators. Blurring and feigning of the results leads to the decisions of the investors, which are not in the function of efficient capital allocation, and we can see that in a number of financial frauds in large and powerful companies in the developed countries. The consequences of the false representation of successful results are the failure of the seemly successful companies overnight, where the burden of the great losses is first suffered by shareholders, and then other investors as well, and the side effect is the spread of distrust in financial market functioning. On the other hand, the existence of the information asymmetry is a regular catalyst of the market inefficiency and instability of the complete financial system. 
Corporate governance is one of the key elements in economic efficiency and growth improvement, as well as investor trust increase. Corporate governance offers the structure with company goals set and allocate the resources to achieve the goals and performance monitoring. Adequate business management should provide the appropriate encouragement for the board of directors and management to focus on the goals of interest for the company itself as well as its shareholders. The existence of the appropriate system of corporate governance, within individual companies and the economy as a whole, helps in providing a certain level of trust necessary for the market economy to function in the appropriate way.

\section{The importance of accounting and financial reporting in a market economy}

Investors need transparent and reliable information that accurately reflects the financial situation of a company in order to enable the smooth functioning of the market and efficient capital allocation. In the world that is becoming more globalised, the investors seek opportunities to compare the companies in important parameters in order to make rational business decisions about investments. Accounting is becoming more globalised as the companies are becoming more multinational, and the scope of trade and investments between the companies increases all the time. These factors reinforce the need for financial reports which will be internationally comparable and consistent.

According to the Committee for the international accounting standard frame, the point of all financial reports is:

- To present the information on the financial position, business and changes in the financial position of the entity. The financial reports prepared for these purposes satisfy the usual needs of most users. However, the financial reports do not offer all the information the users might need to make economic decisions, because they largely reflect financial effects of the previous events, and they do not necessarily contain non-financial information;

- To show the results of the management work, that is, their responsibility for the available resources entrusted to them. The users of the information who want to evaluate the work or responsibility of the management do that in order to be able to make important economic decisions, the trust to the existing management among other things.

In order to achieve the above mentioned goals, the information about property, liabilities, capital, cash flow, income and costs are contained in the financial reports of companies.These information, with other data cited in the notes of the financial reports, help the users to understand the company's business in the previous period and predict the future flow of the company's results, especially the cash flow.

Accounting is the means through which we measure and describe the results of the economic activity. It is the way in which the business people define the business goals, measure the achieved results and assess the future performance. The basic purpose of accounting is to provide the information for the decision makers useful for making the vital economic decisions. Therefore, we can rightfully say that the economic activity in terms of business transactions appears as the input in the process of accounting, and the output or result is the useful information (Martac, S. 1998, International financial reports - similarities and differences, XXIX Symposium of the Association of Accountants and Auditors of Serbia, Zlatibor, Proceedings). 
The primary goal of accounting consists of providing complete understanding of the nature of the accounting information, as well as to nurture the ability to use the information efficiently. It serves as a buckle that directly connects the decision makers with the economic activities - and thus, indirectly, with the results of such decisions. The efficient usage of the accounting information assumes the complete understanding of the nature of the economic activities included in the financial reports, the understanding of assumptions and measuring techniques used in the accounting process, as well as understanding the ways of linking the current accounting information with future business decision making.

The purpose of financial reporting is, primarily, the creation of information useful for making decisions of financial nature. Thereby, the decisions of the investors, creditors and other external stakeholders of the company are primarily taken into account (Stefanović, 1995). They have different information needs depending upon the nature of the decisions made on the basis of the acquired information. It is in the investors' interest to make a portfolio which consists of such investments that direct the capital towards the areas of its most profitable usage.

Providing high quality of the financial reports, apart from respecting professional and legal regulation, also means respecting ethical norms, that is, ethical behaviour of the financial report creators. It is especially important to harmonise the accounting and auditory practice which facilitates accounting and financial communication among business entities around the world, enabling a method to span the accounting obstacles that stand in the way of achieving a greater degree of freedom in the flow of goods, services and capital. (Leković, M., Arsenović, S., (2013). The role and importance of good-quality financial reporting, Banking, no 4, pp 79-93).

Business entities gained access to a large number of markets around the world and opportunities to make a geographical selection at raw material procurement and their own product placement, whereby they often decide to do that outside their own countries. These modern terms of doing business offer a whole spectre of new development and advancement opportunities for business entities. However, it includes widening the circle of stakeholders who are trying to gain insight into the way of doing business within the company and its performances. The possession of the relevant information on the efficiency of the use of capital in the company in the previous period, as well as business potential to be used in the future, is of crucial importance for investors when they choose the way for the placement of their funds.

The investors' interests are in collision with the differences in the way of formatting accounting information which makes them one of the key driving forces of change in the system of financial reporting, demanding its harmonisation. Thanks to the standardised and goodquality financial reporting, information asymmetry and negative selection are reduced, which offers more security to investors. This is the way to encourage investment and greater capital mobility, and the result is also more efficient functioning of the capital market, which represents an important determinant in the development of every country.

To provide a fair and good-quality financial reporting implies respecting not only legal, but also ethical norms. 
Professional and legal regulation represent the minimum standards of behaviour for professional accountants and all the people taking part in compiling financial reports, and the ethics supplements that (Malinić, 2011). Blurring and feigning of the results leads to the investors' decisions which are not in the function of efficient capital allocation. True and honest financial reporting represent a first class public interest (Stevanović, 2011), and therefore the principle of objective reporting should be the leading principle of the financial report creators.

The financial information prepared according to the accounting principles can significantly deviate from the ones based on the concept of the economy. That is to say, the basic objection to the accounting is that it does not take opportunity costs into account. This is the reason for correcting the accounting data for the investment decision needs, in order to have a more realistic picture about the efficiency of a certain investment. Some of the characteristic examples include the differences in the structure of the economic and accounting gain, economic value added, market value added, etc. (Malinić, Savić, 2011). The above mentioned economic terms often involve the use of dynamic methods and future gain prediction in decision making. At the same time, it causes accounting limitations, and that is being static and not respecting the time value of money.

The basic goals of the Principles of corporate governance (Jonston, 2004) are reflected in: economic efficiency improvement, business entity and economic growth on one hand, as well as confidence strengthening and financial market development on the other. In the context of the Principles of corporate governance, the accounting profession activities are treated as an integral part of management, with the specific rights and responsibilities (Vidaković, 2009). The role of the accounting profession itself in the OECD principles is providing all the relevant accounting information in order to protect the equality between domestic and foreign shareholders, especially between majority and minority shareholders. The accounting profession, apart from its basic role of the stakeholder interest protection, should offer information for the basic functioning of the management, and they are: corporate governance strategy and revision, risk assessment, business plan and budget adoption, company success control, capital investment control, acquisition control and company sale control.

The more developed the economy, the greater the importance given to a goodquality financial reporting. Market economy development goes hand in hand with the pace of the accounting profession development and the quality of the financial reporting. This is the reason for investors to opt, as a rule, for the markets they know and trust. The investors have larger confidence in those countries that have already adopted and applied the international standards for financial reporting. Providing information on the basis of the standards that is of goodquality, transparent and comparable largely reduces the investment risk and cost of capital raising.

\section{The negative effects of the information asymmetry in modern markets}

The arguments about the role of the companies in the society are very often. They are about whether the companies should have the exclusive goal to maximise the value for the shareholders or try to satisfy the interests of all the stakeholders, which are often conflicted. 
The shareholders' theory is based on their primacy, while the stakeholders' theory claims that the others should also be taken into account. According to the first theory, the duty of the management is to maximise the return on equity, while according to the other theory the duty of the manager is to balance the shareholders' financial interests and the interests of other stakeholders, such as the employees, clients and local community, even at the expense of the reduction in yield for shareholders. (Kothari, J., Barone, E. (2012). Financial accounting, the international approach, DATA STATUS, Belgrade).

The company management has all the information created within the organisation at their disposal. The decisions of the management are mostly based upon the information originating from the accounting system. However, most of the information available is also delivered to stakeholders outside the company. There is a logical question of the kind of safety the users outside the company have about whether the financial reports presented by the management offer complete and reliable picture of the business results and company's financial position. For the most part, this safety is provided through the auditing of financial statements by an independent auditing company.

In the modern economy, the sources of the competitive advantages are based on non-material resources, such as workforce skills, reputation, leadership, innovation, etc. The nature of the resources themselves means that there is a little probability that their value will be revealed in the current framework of the financial reporting.

The characteristic of the modern environment is company knowledge in the area of high information technology, car and pharmaceutical industry. Nowadays, the worth of the company is not only assessed on the basis of total income, share in the market or the ratio of prices and net profit per share, but on the basis of intellectual capital such as branding, client loyalty, organisational culture, etc. It is pointed out that the traditional indicators used in the assessment of non-material property is outdated and there is an increasing need for the creation of a new system of assessing non-material investment. Also, important attention is paid to the problems of inadequate disclosure and presentation of a nonmaterial property according to the accounting standards, rules and guidelines set by the International accounting standards, and business entities have an obligation to apply them in the course of non-material property recognition and validation.

An important obstacle to the productive use of capital, which enables hiding the true performances of the company is the information asymmetry. The information asymmetry makes it feasible to feign the company's results and that causes sending the wrong signals to the investment public. In these conditions, seemingly successful companies collapse overnight, where the burden of great losses is taken the shareholders before everyone else, and then the other investors as well, with the side effect of spreading distrust in financial market functioning. The existence of the information asymmetry is a regular catalyst of the market inefficiency and instability of the complete financial system. We speak of the information asymmetry when there is a different level of awareness of the two sides in an economic transaction. The asymmetry always goes into the same direction - the seller knows more than the buyer (Ritter et al, 2004). 
The best example is the information asymmetry between the emitter company on one hand, and the current and potential investors on the other.

The information available to the narrow group of investors put small and unsophisticated investors into the inferior position, causing them to suffer a significant damage. It is the reason for the laws which regulate the circulation of securities to prohibit the use of the so called privileged information. The above mentioned privileged information on the company's business represents a trade secret, and as such it is not available to the public. However, their abuse in the capital market shows a character of the information asymmetry, and points to inadequate legal protection of the investors (Malinić, Savić, 2011). In these conditions, the demand for financial information decreases due to the loss of confidence of the investors.

When it comes to the incomplete information as a result of the agency relations, four following axioms show what happens if the financial reports ,do not show the whole picture" (Paul, 2002): uncertainty;

- incomplete information increase

- incompletness creates risk;

- the risk causes the investors to ask for a higher yield rate;

- it further increases the cost of capital and decreases the cost of shares.

The financial reports do not include numerous financial, ecological and legal aspects of the environment, then the trends and changes that should be considered for the needs of the company's perspective assessment, that is, the chances and dangers that result from the environment where the company exists. The examples include the potential market for products, price restriction, export reduction, ecological standards and other factors defining the existing and future position of the company. The additional reason for non-disclosure of information is a possibility of losing the competitive ability of the company, that is, additional risk exposure (Bazley et al, 1999).

The utility of financial reporting should not be appreciated only in relation to the individual users, but also from a wider economic perspective, that is, a social point of view. In terms of the financial reporting, apart from other relevant factors, this must be in the focus of the primary goals, to bear in mind the provision of higher level of general social prosperity as the main strategic goal of every society. In other words, it is reasonably considered that the quality of the financial reporting in a country is directly proportional to the general economic prosperity of the country (Milojević, D., (2006). Financial audit reporting, BBA, Belgrade, FTB Belgrade).

In theory, the shareholders control the company's business, but in practice, the situation is somewhat different in shareholders' companies. The shareholders only choose and establish the management, and the managers lead the company's business. The managers are, in fact, the agents who should do business in the shareholders' interest, while they are the principals here. The managers often work for their own interests in practice, at the expense of shareholders and other stakeholders. In practice, the managers who continuously make harmful decisions to stakeholders suffer strict sanctions. The companies where the share price represents underestimated value due to underutilised resources become easy targets for the investors interested in the purchase of such companies. 
A large number of managers are focused on creating short-term benefits for themselves, while the investors are primarily interested in the company survival and development, that is, longterm objectives. Successful companies are the ones that where the interests of shareholders as capital owners, and the managers as business enterprise managers are in balance. (Žarkić, J., Benković, S., Milosavljević, M., (2013). Financial management, FOS, Belgrade).

\section{Business reporting and corporate governance}

Corporate governance is one of the key elements in economic efficiency and increase improvement, as well as investor trust increase. Corporate governance includes a set of relations between the company management, its board of directors, its shareholders and other stakeholders. Corporate governance also offers the structure where the goals of the company are set and resources allocated for the achievement of the goals and performance monitoring. The adequate business management should provide the appropriate incentive for the board of directors and the management to focus on the goals in the best interest of the company and its shareholders. The existence of the appropriate system of corporate governance within the individual companies and the economy as a whole, helps to provide a certain level of confidence necessary for the market economy to function in the appropriate way. As a result, capital cost is reduced, and the companies are encouraged to use the resources more efficiently, which lays the foundations of the development. Corporate governance is only a part of the larger economic context in which the companies do business, and it includes, for example, macroeconomic policies and a certain level of competition in the product and factor market. (OECD Principles of Corporate Governance, 2004).

The corporate governance framework depends on the legal, regulatory and institutional environment. This framework should provide that all the tangible issues about the company are timely and accurately disclosed, including the financial situation, business performances, ownership structure and company management. Furthermore, the factors such as business ethics and corporate awareness about the interests of the communities where the company does business connected to the social and life environment can also influence the reputation of the company and its longterm success.

Corporate governance refers to a series of rules that a company implements in its business. These rules represent the guidelines that the managers follow in achieving various goals of the company, including share price maximisation. It is important for the company to clearly define the structure of its corporate governance so that the individuals and entities interested in the prosperity of the company can realise the manners in which their interests will be respected. As a result of Sarbanas-Oxley Act in 2002 and increased pressure of the shareholders, most of the companies in the USA carefully write out their corporate governance policies in order to enable all stakeholders to realise their rights and obligations in a better way (Besley, S., Brigham, E., (2015). Business finances, DATA STATUS, Belgrade).

The studies show that the companies with the practice of good corporate governance achieve higher returns for shareholders. 
They also show that the companies developing the structures of corporate governance make the identifying and correcting of the accounting problems easier, and they show better performances than the companies with weak corporate governance policies (internal control). According to Vidaković (2007), the goals of corporate governance are shareholder protection, financial and capital market stabilisation and development, and stable development of the economy. In the countries of the developed market economy, three systems of corporate governance are differentiated (Lovre, 2014):

* One-tier corporate governance system, which is the characteristic of the Anglo-Saxon countries (USA, UK, Canada).

* Two-tier corporate governance system, characteristic of Germany and Japan.

*Mixed model of corporate governance where the characteristics of both models are present, accepted in the countries in transition

The awareness about corporate governance and its role in the global economy increases constantly and steadily in the recent years. In the developed economies, where active markets for corporate control and diversified ownership structure makes it more difficult for the shareholders to monitor the management, questions about management are asked more often, and the practices of company management are regularly and closely monitored by the general public. Corporate failures of some prominent companies in the USA and Europe result in increasing attention paid to corporate governance as an independent risk factor in the developed markets. Also, in the markets of the developing countries, financial crisis discovered great imperfections in corporate management practices.

Stock exchange and regulatory bodies across the world tend to set the standards or codices of the best corporate management practice. The investors started to check the corporate governance practice more systematically as a component of the decision making process in the companies. The argument on corporate governance is increasingly taking place outside the limits of the shareholders of the company and it involves other stakeholders such as creditors, buyers, environment and local community experts. Bad practice of corporate governance is closely connected to bad financial reporting and corporate data disclosure. The basis of any corporate governance structure is disclosure of reliable and authentic financial information. Transparency is the basis of the public confidence in the corporate system, and the funding will pour into the centres of economic activities that encourage confidence. (Kothari, J., Barone, E., (2012). Financial accounting the international approach, DATASTATUS, Belgrade, pp 326-327).

There are a number of cases of the companies that failed, even went bankrupt, due to the weaknesses in financial management and corporate data disclosure: on a world scale, there are famous cases of Enron, WorldCom, Global crossing, Tyco, Xerox, Parmalat, Adecco, Vivedni, etc. It had a cumulative negative effect on the formation of the expert opinion on financial reporting. There is a great concern in terms of market economy functioning where the shareholders, employees and retired people lost large sums of money, while the ones running the companies and held responsible for the losses still made money despite the failure of the company. 
In some of the cases, fraud and deception spread even to the auditors, legal advisors and board of directors. Financial reports have always been one of the main methods of the company to offer information to its shareholders and potential investors. The result of the decreasing interest for financial information and corporate data disclosure is sometimes the withdrawal of the investors, which then results in higher capital costs. That is why the productivity of the company decreases and threatens to endanger the smooth functioning of the market economy.

Reporting on financial and other corporate information is an interactive process, and it includes constant communication and contact between a number of participants. The process flow begins with corporate management, and ends with the investors and stakeholders, who are the information users. Along the course of the process, there are some of the bodies setting up the rules and standards, regulatory authorities applying them, legal and other advisors in the process. The development of information technologies provides access to financial information and its use for the investors.

\section{Conclusion}

The skepticism of external users concerning truthfulness and objectivity of the financial reports, that is, fair and honest representation of the company performances is understandable, bearing in mind a large number of manipulations, fraud and accounting tricks with the aim of covering up the real position of the company and showing its more favourable financial result. Managers and accountants use creative accounting in order to get to new credits more easily, attract new investors, achieve higher bonuses and compensations, etc. The brunt of the financial manipulations, which ultimately often lead to the company failure, is borne by the shareholders and investors. The result of all that is widespread of general distrust in the functioning of the financial markets and it is reflected through economic activity reduction.

The usefulness of the financial reporting should be appreciated not only in relation to the individual users, but also from a wider economic perspective, that is, social point of view. Financial reporting, apart from a series of other relevant factors, should have the provision of as high level of general social prosperity as possible in the focus of its primary goals. The investors' interests are in collision with the differences in the methods of accounting information formatting, and that is why they become one of the key drivers of change in the financial reporting system, demanding its harmonisation. Thanks to the standardised and goodquality financial reports, the information asymmetry and negative selection are reduced, and it offers more security to the investors. This is the way to encourage investments and better capital mobility, and the result is also a more efficient functioning of the capital market, which represents an important determinant of the economic development in every country.

The appropriate system of corporate governance in the economy as a whole can provide a certain level of trust necessary for the market economy to function in the appropriate way. As a result, capital cost is reduced, and the companies are encouraged to use the resources more efficiently and to focus on the goals in the interest of the company and its shareholders, which lays the foundations of the development of society. The reporting on financial and other corporate information is an interactive process, and it involves constant communication and contacts between many participants. 
The interaction between the national and international development in corporate governance and corporate reporting has the key importance. The most important elements are transparency, responsibility and integrity, and they create the public confidence in the market, therefore providing the efficient allocation of capital.

\section{References}

[1] Bazley M., Hancock P., Berry A., Jarvis R., (1999). Contemporary accounting, Thompson Learning

[2] Besley S, Brigham, E., (2015). Business finances, DATA STATUS, Belgrade

[3] Jonston, D.J., (2004). OECD The principles of corporate governance 2004, Belgrade. OEBS mission in Serbia and Montenegro: economic issues and environment policy sector

[4] Kothari, J., Barone, E., (2012). Financial accounting, the international approach, DATA STATUS, Belgrade

[5] Martić, S., (1998). The international financial reporting - similarities and differences, XIX Symposium of the Association of Accountants and Auditors of Serbia, Proceedings, Zlatibor

[6] Milojević, D., (2006). Financial audit report, BBA, Belgrade, FTB Belgrade

[7] Žarkić, J., N., Benković, S., Milosavljević, M., (2013). Financial management, FOS, Belgrade

[8] OECD Principles of Corporate Governance, 2004

[9] Kothari, J., Barone, E, (2012). Financial accounting - the international approach, DATASTATUS, Belgrade, pp 326-327

[10]Leković, M., Arsenović, S., (2013). The role and importance of the good-quality financial reporting, Banking no 4, pp 7993

[11]Lovre, I., (2014). The role and importance of accounting and audit in corporate governance, The School of Business, no 1/2014, Novi Sad
[12] Stefanović, R., (1995). The accounting principles and standards of the financial reporting, Finances, no. 11-12, pp 722-729

[13] Malinić, D., (2011). The ethical dimension of the quality of financial reporting, Ekonomika preduzeca, no. 5-6, pp 243261

[14]Paul B.W., (2002). "Quality financial reporting", Journal of Accountancy

[15]Ritter, L., Silber, W., Udel, G., (2004). Principles of money, banking and financial markets. Boston: Pearson Education

[16] Stevanović, N., (2011). Financial reporting responsibility in the context of the EU, international and new domestic regulatory framework, Ekonomika preduzeca, no. 5-6, pp 227-242

[17]Malinić, S., Savić, B., (2011). The transformation of corporate reporting from financial to business reporting, Economic horizons, no. 13, pp 105-124

[18] International Survey of Corporate Responsibility Reporting 2008, KPMG

[19] Vidaković, S, V., (2007). Financial due diligence of the business companies, Faculty of business in service, Novi Sad

[20] Vidaković, S, V., (2009). Audit: the basis of competence, credibility, trust. Faculty of business in service, Novi Sad 